\title{
Effect of Dietary Crude Protein Level of Feed on Growth and Survival of Rohu Fry
}

Surendra Prasad, Ram K. Shrestha and Md. Akbal Husen

Fishery Research Station, Pokhara, Kaski, Nepal

\begin{abstract}
Fry rearing is one of the important stage which aims at obtaining high growth and survival for production of fingerlings required for stocking into grow out ponds as well as rehabilitation in natural habitat. This experiment was conducted with the purpose to test the effect of dietary crude protein level (CP \%) of feeds prepared from similar feed ingredients in different ratios on growth performance and survival rate of Rohu fry (Labeorohita). An initial density of $100 \mathrm{fry} / \mathrm{m}^{2}$ was maintained in hapa fixed in the cemented tank. The dietary CP\% level of feed tested were $20 \% \mathrm{CP}, 25 \% \mathrm{CP}, 30 \% \mathrm{CP}$, and $35 \% \mathrm{CP}$ fed at $5 \%$ body weight. The experiment ran for 53 nursing days. The results showed that there was no significant difference $(P>0.05)$ in the growth rate $(\mathrm{g} / \mathrm{day})$ of fry among treatments. Rather group fed with higher protein level grew comparatively better indicating possibility of increasing need of protein in diets. However, the survival rate $(\%)$ of rohu fry was significantly different $(P<0.05)$ in each tested $\mathrm{CP} \%$ level of feed. Highest survival (82\%) of fry was found in the feed of CP $35 \%$ and lowest (56\%) in the feed of CP $25 \%$. It was predicted that feed with increasing level of $\mathrm{CP} \%$ in diet is essential for increasing survival rate.
\end{abstract}

Key words: Rohu fry, Labeo rohita, growth rate, crude protein, fish survival.

\section{Introduction}

The modern aquaculture started in the 1950s in Nepal. Semi-intensive carp polyculture is the major established aquaculture in Nepal. Rohu is most cultured fish in the polyculture with other carps in semi intensive fish culture in Nepal. It is preferred by consumers of Nepal that's why it fetches high price in the market. Fish seed is the most important input in aquaculture in Nepal. The demand of fish seed is in increasing trend due to expansion of aquaculture area. Its supply is challenging both in terms of quantity and quality [1]. To ensure the maximum survival rate of fish fry, it needs good nursing practices.

Protein is the major dietary nutrient affecting performance of fish [2]. It provides the essential and nonessential amino acids which are necessary for muscle formation and enzymatic function and in part provides energy for maintenance [3]. Protein in diet enhances the growth of fish regardless of species

Corresponding author: Surendra Prasad, MS., senior scientist, research fields: fish breeding and fish disease. weight groups and the dose [4]. It is usually the expensive major constituent in a diet. Therefore, dietary protein level in fish feed needs to be optimized accurately for particular fish and its stages. The objective of the study was to test the effect of dietary crude protein level (CP \%) of feeds prepared from similar feed ingredients in different ratios on growth performance and survival rate of Rohu (Labeo rohita) larvae.

\section{Materials and Methods}

This experiment was conducted at FRS, Pokhara, Kaski using fry of Rohu, Labeorohita in the hapa (1 m $\times 1 \mathrm{~m} \times 1 \mathrm{~m}$ ) fixed in cemented tank. The stocking was done at the density of 100 fry/hapa. The fry was fed at the rate of $5 \%$ body weight three times a day with four different levels of crude protein feed. The CRD design was used for the experiment. Tested treatments were: T-1 (Feed with CP 20\%), T-2 (Feed with CP 25\%), T-3 (Feed with CP 30\%) and T-4 (Feed with CP 35\%). Feed compositions are presented in Table 1. The growth and survival were recorded in every 15 days 
Table 1 Treatments and compositions of experimental feed for Rohu fry.

\begin{tabular}{lllll}
\hline Ingredients & $\mathrm{T} 1(20 \% \mathrm{CP})$ & $\mathrm{T} 2(25 \% \mathrm{CP})$ & $\mathrm{T} 3(30 \% \mathrm{CP})$ & $\mathrm{T} 4(35 \% \mathrm{CP})$ \\
\hline Shrimp & 5 & 10 & 20 & 30 \\
Soyachoker & 8 & 15 & 24 & 30 \\
Oilcake & 24 & 30 & 22 & 20 \\
Ricebran & 42 & 28 & 20 & 6 \\
Wheat & 10 & 10 & 8 & 8 \\
Maize & 10 & 6 & 5 & 5 \\
Vita mix & 0.2 & 0.2 & 0.2 & 0.2 \\
Mineral mix & 0.8 & 0.8 & 0.8 & 0.8 \\
Total & 100 & 100 & 100 & 100 \\
\hline
\end{tabular}

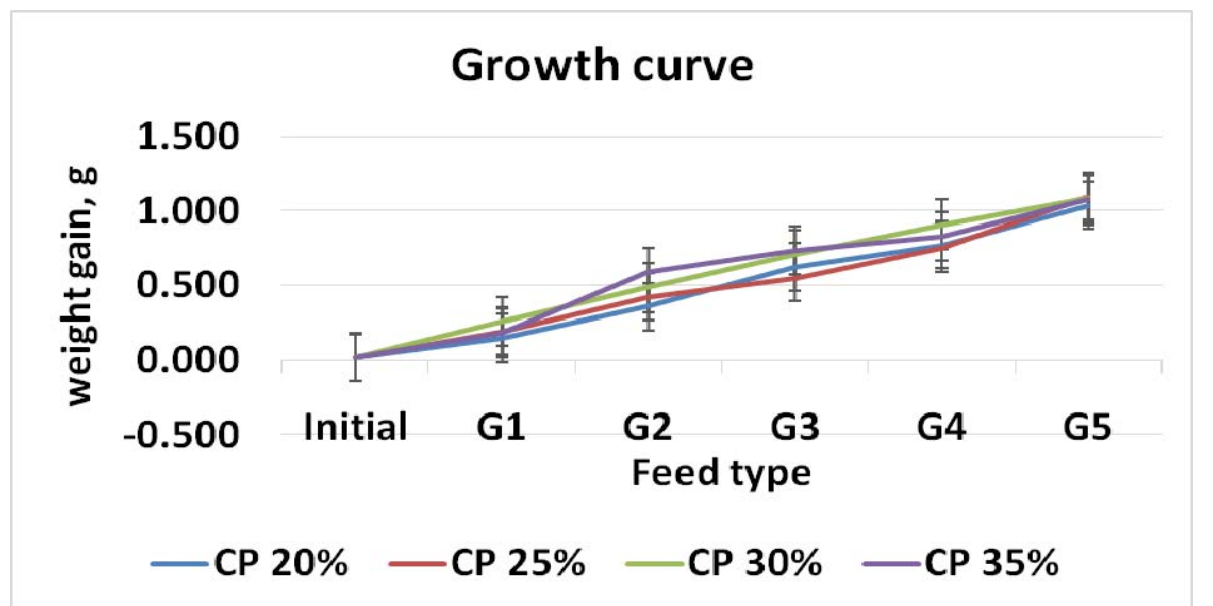

Fig. 1 Growth trends of Rohu larvae feeding with different level of crude protein feed.

interval and water quality parameters were checked in each day for temperature, $\mathrm{pH}$, and dissolved oxygen (D.O.). The culture period was 53 days. Growth and feed efficiency parameters were calculated based on the following formulae:

Mean weight gain $(g)=$ Mean final weight - Mean initial weight

Specific growth rate $(\mathrm{SGR}) \%=$ $[(\operatorname{lnFW}-\ln I \mathrm{~W}) /$ number of culture days $)] \times 100$

Feed conversion ratio $(\mathrm{FCR})=$ dry feed intake $(\mathrm{g}) /$ wet weight gain $(\mathrm{g})$

where IW = Initial weight, FW = Final Weight

Statistical analysis of the data was performed using SPSS software program (SPSS 15. Chicago, IL, USA). One-way Analysis of Variance with Tukey's test was used to compare the different feed groups.

\section{Results and Discussions}

Water quality recorded during the study periods were: water temperature $28.06 \pm 1.8, \mathrm{pH} 7.5$, and D.O. $8.7 \pm 1.8$. The results showed that there was no significant difference $(P>0.05)$ in the growth rate (g/day) of fry among treatments. Rather group fed with higher protein level grew comparatively better indicating possibility of increasing need of protein in diets (Fig. 1). However, the survival rate (\%) of Rohu fry was significantly different $(P<0.05)$ in each tested $\mathrm{CP} \%$ level of feed. Highest survival $(82 \%)$ of fry was found in the feed of CP 35\% and lowest (56\%) in the feed of CP 25\%. The results showed that increasing dietary protein level has significant effect on the survival of fish larvae. Previous studies showed that the optimum protein requirement for Rohu larvae and fry varies from $35 \%$ to $45 \%$ [5-7]. In the present study, FCR decreased with the increased in dietary protein level (CP 30\%-35\%). It was concluded that FCR decreased with the increased in dietary protein level in feed of Rohu fry [4]. 
Table 2 Fish fry growth and survival in hapa feeding with different protein level.

\begin{tabular}{lllll}
\hline Parameter & \multicolumn{3}{c}{ Treatments } \\
\cline { 2 - 5 } & T1 $(20 \% \mathrm{CP})$ & $\mathrm{T} 2(25 \% \mathrm{CP})$ & $\mathrm{T} 3(30 \% \mathrm{CP})$ & $\mathrm{T} 4(35 \% \mathrm{CP})$ \\
\hline Initial weight $(\mathrm{g})$ & $0.018 \pm 0.036^{\mathrm{a}}$ & $0.018 \pm 0.036^{\mathrm{a}}$ & $0.018 \pm 0.036^{\mathrm{a}}$ & $0.018 \pm 0.036^{\mathrm{a}}$ \\
Final weight (g) & $1.035 \pm 0.06^{\mathrm{a}}$ & $1.096 \pm 0.285^{\mathrm{a}}$ & $1.088 \pm 0.172^{\mathrm{a}}$ & $1.072 \pm 0.104^{\mathrm{a}}$ \\
Mean weight gain (g) & $1.02 \pm 0.01^{\mathrm{a}}$ & $1.08 \pm 0.28^{\mathrm{a}}$ & $1.07 \pm 0.12^{\mathrm{a}}$ & $1.05 \pm 0.11^{\mathrm{a}}$ \\
${\text { SGR }\left(\% \text { day }^{-1}\right)}^{\text {Survival rate (\%) }}$ & $7.69 \pm 0.42^{\mathrm{a}}$ & $7.75 \pm 0.50^{\mathrm{a}}$ & $7.77 \pm 0.18^{\mathrm{a}}$ & $7.75 \pm 0.53^{\mathrm{a}}$ \\
FCR & $62 \pm 0.58^{\mathrm{a}}$ & $56 \pm 0.58^{\mathrm{b}}$ & $76 \pm 0.43^{\mathrm{c}}$ & $82 \pm 0.64^{\mathrm{d}}$ \\
\hline All & $0.11 \pm 0.01^{\mathrm{b}}$ & $0.13 \pm 0.01^{\mathrm{b}}$ & $0.08 \pm 0.03^{\mathrm{a}}$ & $0.08 \pm 0.02^{\mathrm{a}}$ \\
\hline
\end{tabular}

All results are expressed as mean \pm standard deviation. $P$ values less than 0.05 were considered as statistically significant.

\section{Conclusions}

This study indicated that 35\% CP feed is needed for the better growth and survival of rohu fry. It could be concluded that feed with increasing level of $\mathrm{CP} \%$ in diet is essential for increasing survival rate. So, further study needed to evaluate the performance of rohu fry with increasing protein level above $35 \%$.

\section{Acknowledgement}

This research was funded by Nepal Agricultural Research Council (NARC) project No-391.

\section{References}

[1] Mishra, R. N., and Kunwar, P. S. 2014. "Status of Aquaculture in Nepal." Nepalese Journal of Aquaculture and Fisheries 1: 1-17.

[2] Lovell, R. T. 1989. Nutrition and Feeding of Fish. New York: Van Nostrand Reinhold, 260.

[3] Yang, S. D., Liou, C. H., and Liu, E. G. 2002. "Effect of
Dietary Protein Level on Growth Performance, Carcass Composition and Ammonia Excretion in Juvenile Silver Perch (Bidyanusbidyanus)." Aquaculture 213: 363-72.

[4] Labh, S. N., Kayastha, B. L., and Ranjan, R. 2014. "Impacts of Varied Proportion of Dietary Protein and Feeding Strategies on the Growth Performance of Rohu Labeorohita $(\mathrm{H})$ in Relation with RNA: DNA Ratio during Intensive Aquaculture." European Journal of Biotechnology and Bioscience 2 (5): 1-8.

[5] Sen, P. R., Rao, N. G. S., Ghosh, S. R., and Rout, M. 1978. "Observations on the Protein and Carbohydrate Requirements of Carps." Aquaculture 13: 245-55.

[6] Mohanty, S. N., Swamy, D. N., and Tripathi, S. D. 1990. "Growth, Nutritional Indices and Carcass Composition of the Indian Major Carp Fry, Catla catla, Labeo rohita and Cirhinus mrigala Fed Four Dietary Protein Levels." Aquacultura Hungarica 6: 211-7.

[7] Mohanty, S. N., Swamy, D. N., and Tripathi, S. D. 1990. "Protein Utilization in Indian Major Carp Fry, Catlacatla, Labeo rohita and Cirhinus mrigala Fed Four Protein Diets." Journal of Aquaculture in the Tropics 5: 173-9. 